Tohoku J. Exp. Med., 1994, 172, 263-273

\title{
Localization of Several G-Protein Subunits in Human Kidney
}

\author{
Shigeto Ishidoya*, Atsushi Fukuzaki and Seitchi \\ ORIKASA \\ Department of Urology, Tohoku University School of \\ Medicine, Sendai 980
}

Ishidoya, S., Fukuzaki, A. and Orikasa, S. Localization of Several GProtein Subunits in Human Kidney. Tohoku J. Exp. Med., 1994, 172 (3), 263-273 - Localization of guanine nucleotide binding protein (G-protein) $\alpha$ chains in human kidney was examined using immunoblotting and immunocytochemical techniques. Immunoblot studies revealed $\mathrm{G}_{\alpha} \mathrm{s}, \mathrm{G}_{\alpha} \mathrm{i}_{1,2}$ and $\mathrm{G}_{\alpha} \mathrm{i}_{3}$ proteins in membrane fractions of glomeruli, cortical tubules and medullary tubules. Immunocytochemical studies confirmed the presence of these G-proteins in several parts of human nephron. The results demonstrate the presence of a large amount of G-protein $\alpha$ subunits in human nephron segments. We speculate that G-protein in human kidney may play an important physiological role well-defined in other mammmalia. _ G-protein; human; kidney; localization

In 1970s it has been suggested that, guanine nucleotide binding proteins (G-proteins) play an important role in the transmembrane signal transduction for hormonal activation of adenylyl cyclase (Rodbell et al. 1971). G-proteins locating at the cytoplasmic surface of the plasma membrane are hetrotrimers composed of $\alpha, \beta$ and $\gamma$ subunits (Hildebrandt et al. 1984; Gilman 1987). The $\alpha$ subunit, which binds GTP and possesses GTPase, is specific to each G-protein (Birnbaumer et al. 1990). It is believed that the variability of the $\mathrm{G}_{\alpha}$ subunits confers functional specificity of G-proteins (Gilman 1987; Birnbaumer et al. 1990). The widely distributed $\mathrm{G} \alpha$ s subunit stimulates adenylyl cyclase, and $\mathrm{G} \alpha \mathrm{i}$ subunit inhibits this process (Gilman 1987; Freissmuth et al. 1989). Obvious function of other G-protein $\alpha$ subunits such as Go or Gt has not been clearly elucidated (Freissmuth et al. 1989; Spiegel et al. 1993).

The role of G-proteins in the signal transduction between receptors and effectors has been intensively studied. Localization of G-protein $\alpha$ subunits in rat kidney was reported by Brunskill et al. (1991), Stow et al. (1991), and Senkfor

Received January 7 1994; revision accepted for publication February 26, 1994.

Address for reprints: Department of Urology, Tohoku University School of Medicine, 1-

1 Seiryo-machi, Aoba-ku, Sendai 980, Japan.

*Present address: Medicine Research, Department of Medicine, The Jewish Hospital of St. Louis, Washington University Medical Center, 216 South Kingshighway, St. Louis, Missouri 63110, USA. 
et al. (1993). However, little has been known about G-proteins in human renal tissue (Nitta et al. 1994). The information of G-proteins in human kidney should be valuable to clarify further mechanisms of the transmembrane signaling processes and pathophysiology of several renal disorders. The present study was designed to characterize the expression and the localization of G-proteins in normal human nephron segments.

\section{Materials and Methods}

Human renal samples used in this study were derived from the kidney surgically extirpated from patients suffered with small sized renal cell carcinoma. Normal cortex and medulla were separated from the tumor. Our pathological inspection confirmed that those kidneys were free from hydronephrosis, nephritis, or other renal diseases. These materials were assured absolutely normal and sufficient for the present purpose.

\section{Antibodies}

Specific peptide antibodies against several G-proteins (RM/1, AS/7, EC/2) were supplied by New England Nuclear (Boston, MA, USA). The specificity of these antibodies has already been reported using cholera toxin and pertussis toxin (Goldsmith et al. 1987; Simonds et al. 1989a, b; Jin et al. 1992). According to their reports, RM/1, AS/7 and EC/2 were specifically immunoreactive to $\mathrm{G} \alpha \mathrm{s}, \mathrm{G}_{\alpha} \mathrm{i}_{12}$ and $\mathrm{G} \alpha \mathrm{i}_{3}$, respectively. Goat anti-rabbit IgG (whole molecule) conjugated with alkaline phosphatase was purchased from Sigma Immunochemicals (St. Louis, MO, USA).

\section{Sample preparations}

Surgically excised human kidney samples were transferred immediately in cold Hanks' balanced salt solution (HBSS) and divided into cortices and medullae. We dissected each sample and prepared glomeruli (GL), cortical tubules (CT), and medullary tubules (MT) by the sieving technique (Brunskill et al. 1991; Jin et al. 1992). We captured GL from 150 $\mu \mathrm{m}$-sized meshes. CT and MT were from $250 \mu \mathrm{m}$-sized meshes. These preparations were identified more than $90 \%$ of purity by microscopic examination. The isolated preparations were washed twice with cold HBSS by centrifugation at 1,500 rpm for $5 \mathrm{~min}$, then washed again with $\mathrm{Ca}^{++}, \mathrm{Mg}^{++}$free HBSS by centrifugation at 1,500 rpm for $5 \mathrm{~min}$, and suspended in appropriate volume $(200$ to $500 \mu \mathrm{l})$ of ice-cold homogenate buffer $(25 \mathrm{mM}$ Tris- $\mathrm{HCl}, \mathrm{pH}$ 7.5; containing $1 \mathrm{mM}$ EDTA, $1 \mathrm{mM}$ dithiothreitol, and $100 \mathrm{KI}$ Units $/ \mathrm{ml}$ of Aprotinin). The samples were homogenated with 10 strokes in the Teflon-glass homogenizer and centrifuged at $3,000 \mathrm{rpm}$ for $30 \mathrm{~min}$. The supernatants were stored at $-70^{\circ} \mathrm{C}$ as cytosolic extracts. The pellets were washed with $1 \mathrm{ml}$ of ice-cold homogenate buffer and centrifuged again at 3,000 rpm for $30 \mathrm{~min}$. The supernatants were discarded and the remaining pellets were resuspended in 200 to $500 \mu \mathrm{l}$ of ice-cold homogenate buffer and stored at $-70^{\circ} \mathrm{C}$ as membrane fractions. The protein content of each preparation was determined by Lowry's method (Lowry et al. 1959).

\section{Electrophoresis and immunoblotting}

Prepared proteins were separated by means of polyacrylamide gel electrophoresis in the presence of sodium dodecyl sulfate as described by Laemmli (1970). The gels containing $13.5 \%$ acrylamide were used to separate G-proteins. Each gel ran with prestained molecular weight markers (Bio-Rad, Richmond, CA, USA) to optimize the separation. Separated proteins were transferred from the polyacrylamide gels to nitrocellulose membranes by the method of Towbin and others (1979). The membranes were washed sufficiently with $20 \mathrm{mM}$ Tris buffer (20 mM Tris-HCl, $\mathrm{pH} 7.5$, containing $500 \mathrm{mM} \mathrm{NaCl}$ ), and exposed to specific 
antibodies against $\mathrm{G} \alpha \mathrm{s}, \mathrm{G}_{\alpha} \mathrm{i}_{1,2}$, or $\mathrm{G}_{\alpha} \mathrm{i}_{3}$ diluted in $1: 1,000$ with the same buffer containing $1 \%$ gelatin and $0.02 \% \mathrm{NaN}_{3}$ at $37^{\circ} \mathrm{C}$ for $60 \mathrm{~min}$. The membranes were washed again with $20 \mathrm{mM}$ Tris buffer containing $0.05 \%$ tween 20 . Goat anti-rabbit IgG diluted 1:1,000 with the same buffer containing $1 \%$ gelatin was used as a second antibody. The membranes were

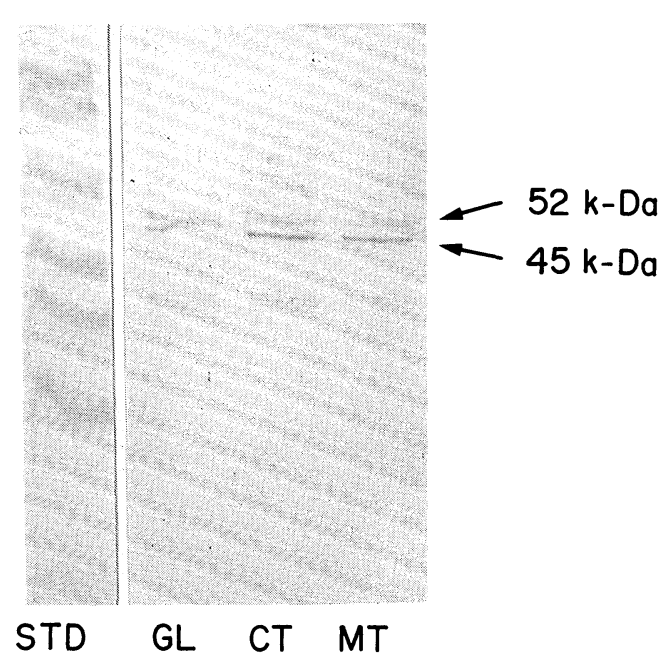

Fig. 1. Immunoblot of membrane proteins from various parts of human kidney incubated with anti-G $\alpha$ s antibody. In each lane, $10 \mu \mathrm{g}$ of proteins are applied from membrane fractions of glomeruli (GL), cortical tubules (CT) and medullary tubules (MT). Numbers represent molecular weights of pre-stained molecular weight standard (STD).

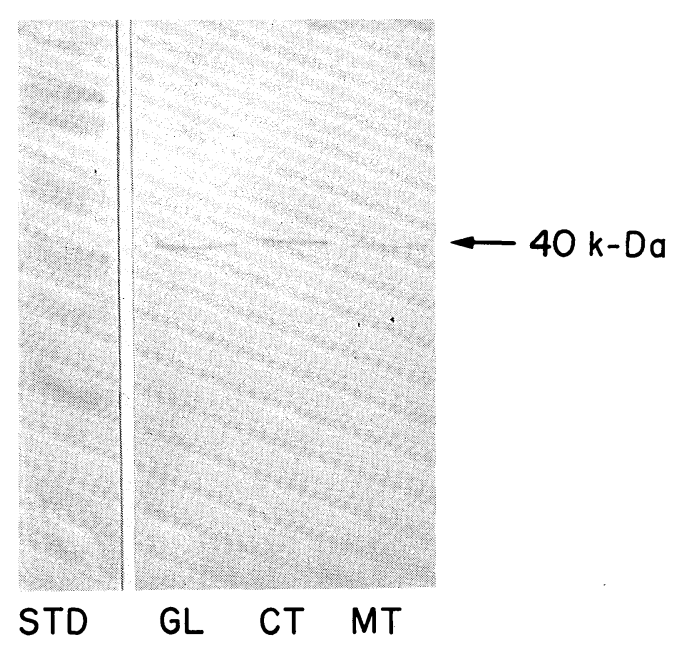

Fig. 2. Immunoblot with anti-G $\alpha \mathrm{i}_{1,2}$ antibody. Membrane proteins of $10 \mu \mathrm{g}$ from human glomeruli (GL), cortical tubules (CT) and medullary tubules (MT) are applied in each lane. 


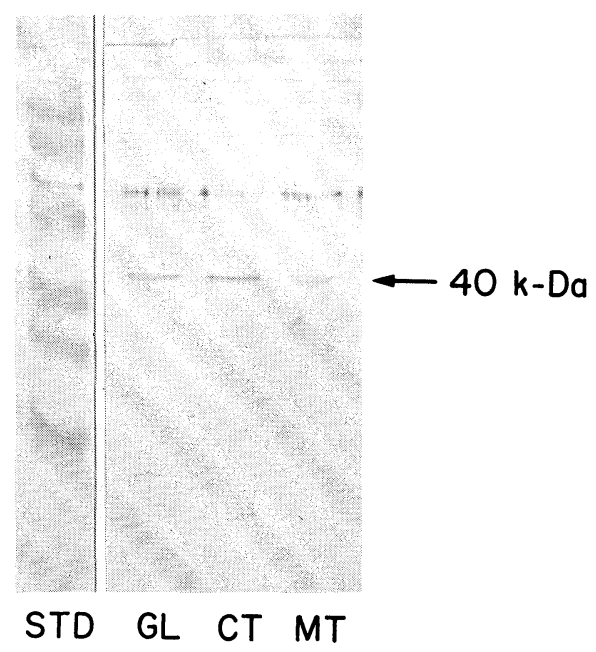

Fig. 3. Immunoblot with anti-G $\alpha \mathrm{i}_{3}$ antibody. Each lane has $10 \mu \mathrm{g}$ of membrane proteins from human glomeruli (GL), cortical tubules (CT) and medullary tubules (MT).

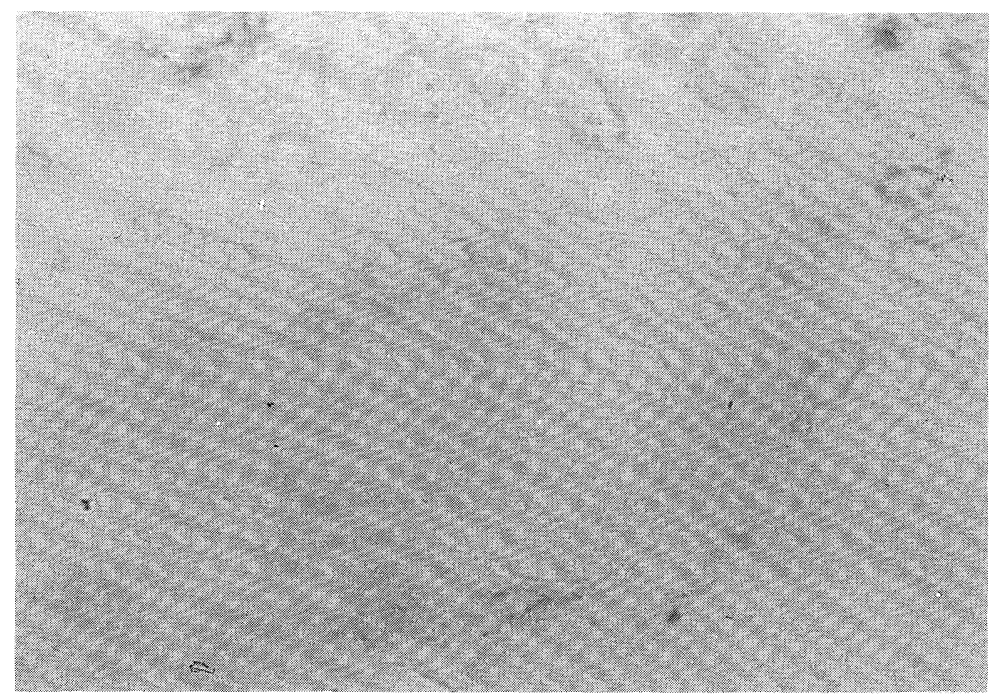

Fig. 4. Immunocytochemical photomicrograph of negative control from human renal cortex.

Fig. 5. Alkaline phosphatase staining immunocytochemical photomicrographs of human kidney sections incubated with anti-G $\alpha$ s antibody. a, View of cortex showing prominent glomerular staining in a mesangial pattern together with intense staining of the proximal tubules and the distal tubules. b, View of outer medulla showing faint staining of medullary collecting tubules. c, Staining in inner medulla is not remarkable. 

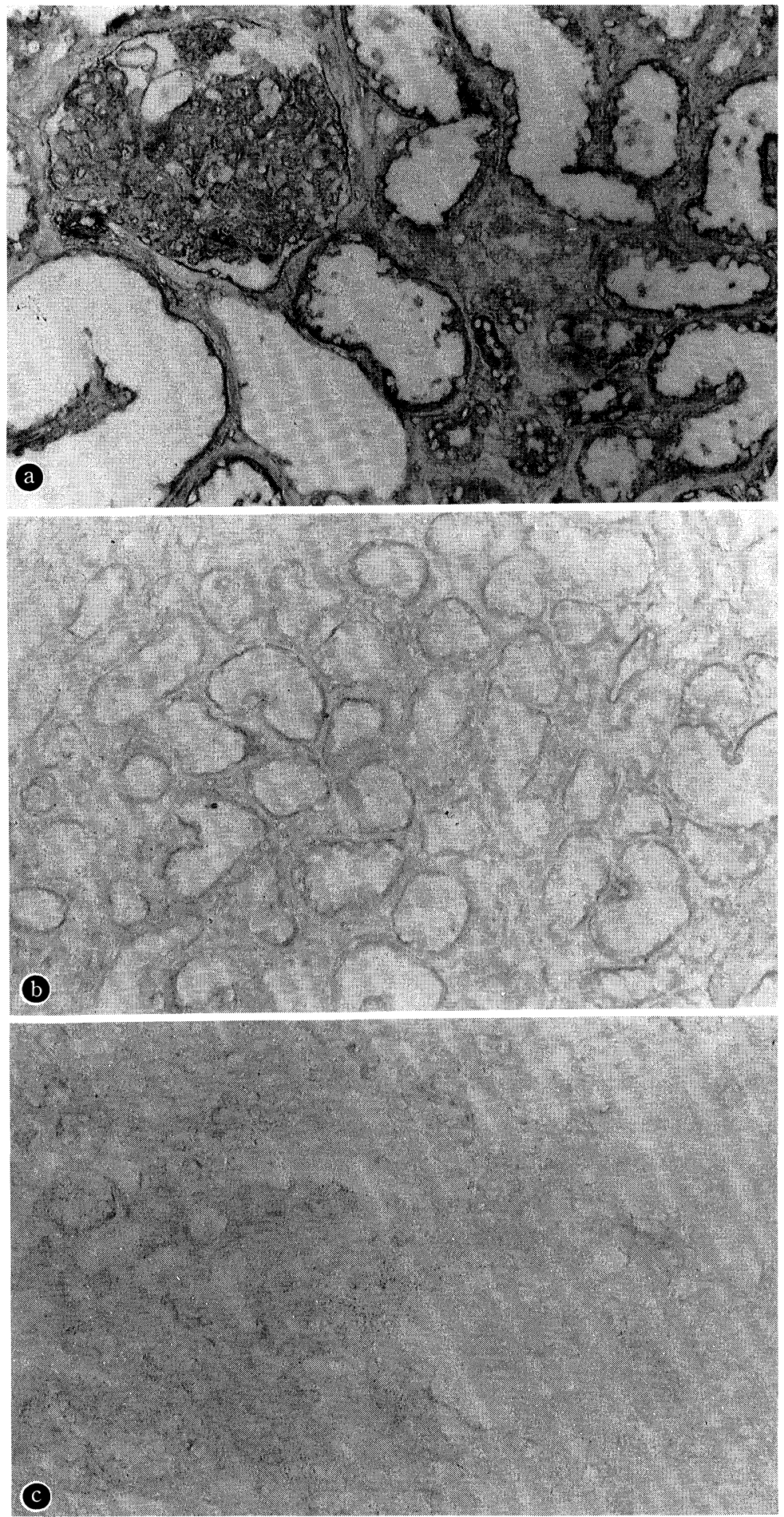

Fig. 5. 
incubated with the second antibody at $37^{\circ} \mathrm{C}$ for $60 \mathrm{~min}$. Incubations were terminated by washing the membrane with $20 \mathrm{mM}$ Tris buffer, and the membranes were stained with nitroblue tetrazolium/5-bromo-4-chloro-3-indoxyl phosphate (NBT/BCIP). Determinations of the level of G-protein expression were carried out by measuring the bands on each membrane with densitometer (Model 620, Bio-Rad) and analyzed by a computer.

\section{Immunocytochemistry}

Some pieces of surgically excised human samples were stored at $-70^{\circ} \mathrm{C}$ in Tissue-tek (Miles, IN, USA). Frozen 5- $\mu \mathrm{m}$ sections of cortices, outer medullae, and inner medullae were mounted on slide glasses coated with poly-L-lysin and washed three times for $5 \mathrm{~min}$ with phosphate buffered saline (PBS), $\mathrm{pH} 7.2$. Sections were incubated with $1 \%$ skim milk/PBS for 30 min to block nonspecifically staining sites. After that, they were incubated with anti-G-protein antibody diluted with $\mathrm{PBS}(1: 80)$ at $37^{\circ} \mathrm{C}$ for $2 \mathrm{hr}$, and washed three times with PBS for $5 \mathrm{~min}$. To detect binding sites of antibodies, the sections were incubated with goat anti-rabbit IgG conjugated with alkaline phosphatase diluted in 1:80 with PBS at $37^{\circ} \mathrm{C}$ for $20 \mathrm{~min}$. The action was terminated by washing the sections with PBS three times for $5 \mathrm{~min}$. We utilized PBS instead of the primary antibody as negative controls. Finally, the sections were stained with BCIP and NBT in $100 \mathrm{mM}$ Tris buffer (100 mM Tris-HCl, $\mathrm{pH}$ 9.5; containing $100 \mathrm{mM} \mathrm{NaCl}, 5 \mathrm{mM} \mathrm{MgCl}$ ) at room temperature for 6 min. After stopping the reaction by washing the slides with distilled water, the sections were dehydrated, embedded and inspected microscopically.

\section{RESUlts}

\section{Immunoblot analysis of G-proteins}

In human kidney, $\mathrm{G}_{\alpha} \mathrm{s}, \mathrm{G}_{\alpha} \mathrm{i}_{1,2}$, or $\mathrm{G}_{\alpha} \mathrm{i}_{3}$ was almost universally identified by immunoblotting of each membrane fraction derived from glomeruli (GL), cortical tubules (CT), and medullary tubules (MT). G $\alpha$ s was demonstrated as a doublebanded protein of 45 - and $52-\mathrm{kDa}$ (Fig. 1). G $\alpha \mathrm{i}_{1,2}$ was noted as a single band protein of $40-\mathrm{kDa}$ (Fig. 2). $\mathrm{G}_{\alpha} \mathrm{i}_{3}$ was similar to $\mathrm{G}_{\alpha} \mathrm{i}_{1,2}$, recognized as a single band protein of $40-\mathrm{kDa}$ (Fig. 3). No differences in the expression levels of each G-protein $\alpha$ subunit were detected among GL, CT and MT by densitometric determination.

\section{Immunocytochemical characterization}

As demonstrated in figures 4 to 7 , the present immunochemical analysis with unfixed frozen sections made it possible to keep sufficient antigenicity and good structural preservation. Background staining or nonspecific alkaline phophatase staining was unremarkable in negative controls (Fig. 4).

When immunostained with anti-G $\alpha$ s antibody, an obvious distribution pattern of immunoreactions was demonstrated throughout the kidney (Fig. 5). In the cortex, intense immunostaining was noted in the epithelial cells of the

Fig. 6. Photomicrographs of kidney sections incubated with anti-C $\alpha \mathrm{i}_{1,2}$ antibody. a, Cortical view showing faint glomerular staining and prominent staining of proximal tubules. $\mathrm{b}$, View of outer medulla demonstrating weak staining of medullary collecting tubules. c, Absence of remarkable staining of inner medullary collecting tubules (right half). 

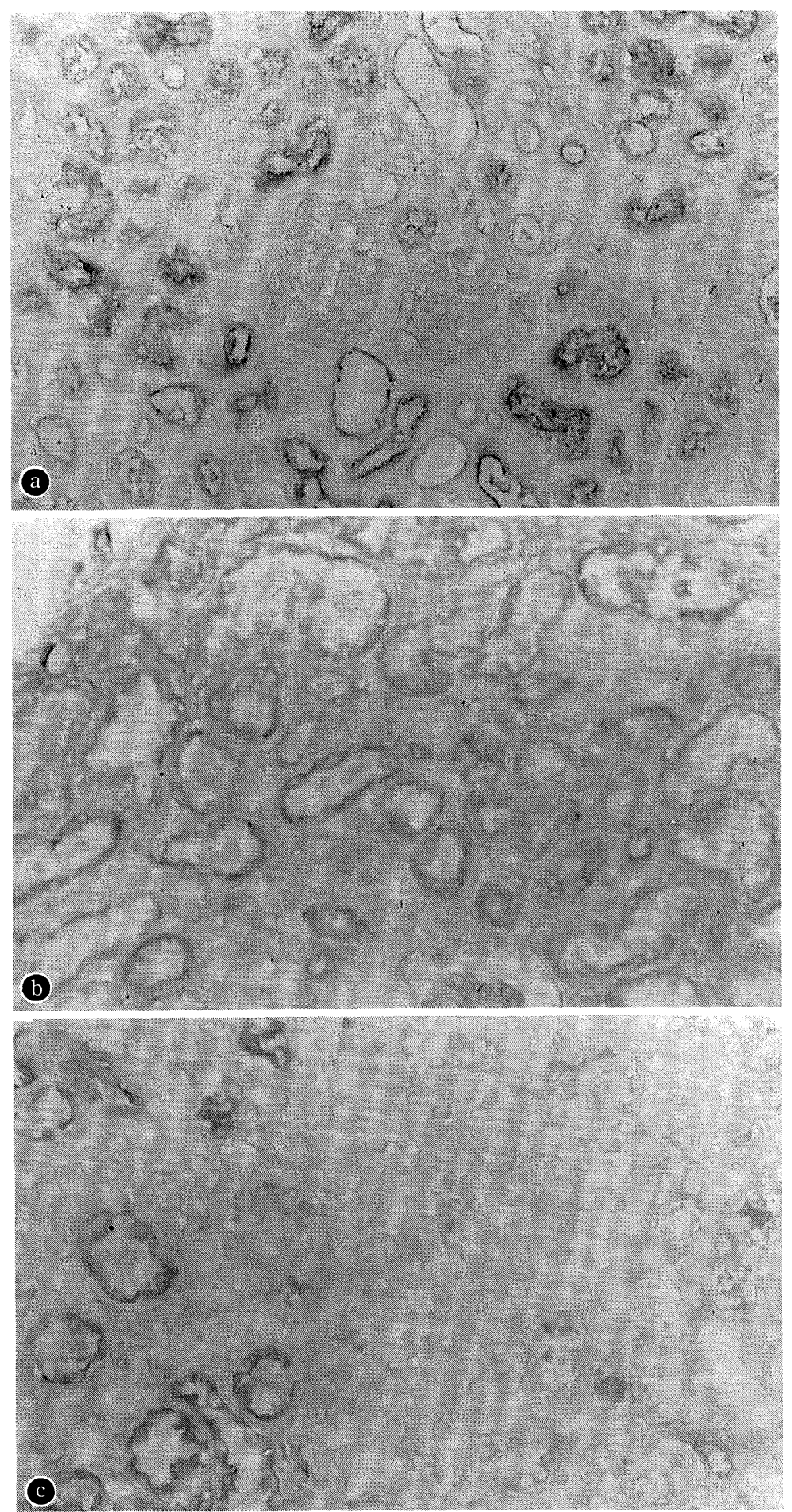

Fig. 6. 
proximal tubules. In the cortical distal tubules, both apical and basolateral portions of the epithelial cells were stained with this antibody. In the glomeruli, the mesangial regions were predominantly stained. Epithelial cells in the medullary collecting tubules were faintly stained, although the intensity was lower in the inner medulla rather than in the outer one.

When stained with anti-G $\alpha \mathrm{i}_{1,2}$ antibody, epithelial cells of the proximal tubules were immunostained, whereas staining of the distal tubules were less prominent (Fig. 6). Weak staining was detected in the glomeruli and the collecting ducts. Both outer and inner medullae were faintly stained.

Sections stained with anti-G $\alpha \mathrm{i}_{3}$ antibody showed almost similar pattern to those stained with anti-G $\alpha \mathrm{i}_{1,2}$ antibody (Fig. 7). In the cortex, intense staining was seen along the brush border sites of proximal tubules, but faint in distal tubules. Immunoreaction was not remarkable in the glomeruli. Both in the outer and inner medulla, cells in the collecting tubules were faintly stained for $\mathrm{G} \alpha \mathrm{i}_{3}$.

\section{Discussion}

There have been accumulated evidences showing the existence and the localization of G-proteins in non-human mammalian organs (Spicher et al. 1988; Murakami et al. 1989; Birnbaumer et al. 1990; Zhou et al. 1990). It is quite reasonable to expect the existence of this membrane-associated G-protein in human nephron segments.

The present results on the localization of G-proteins in the human kidney were quite similar to those of rats (Brunskill et al. 1991; Stow et al. 1991). Immunoreactions for $\mathrm{G}_{\alpha \mathrm{s}}, \mathrm{G}_{\alpha \mathrm{i}_{1,2}}$ and $\mathrm{G}_{\alpha} \mathrm{i}_{3}$ were observed in brush border regions of the proximal tubules, and apical and basolateral membranes of the distal tubules in human renal cortices. The fact no glomerular staining was seen with anti-G $\alpha \mathrm{i}_{1,2}$ or anti-G $\alpha \mathrm{i}_{3}$ antibody was also the same as Brunskill's data studied in the rat nephron segments (Brunskill et al. 1991). These similarities suggest that G-proteins in human kidney may exert the same physiological function that has been defined well in rat kidney and cultured mammalian kidney cell lines (Cantiello et al. 1989). Mohrmann et al. (1987) reported the role of G-proteins in the regulation of $\mathrm{Na}^{+}$transport and ion channels in LLC-PK1 cells.

We used immunocytochemical techniques in human kidney sections to confirm and extend our findings using immunoblots. In this study, we could not definitely clarify the polar distribution of G-protein $\alpha$ subunits between apical and basolateral membrane. Previous studies have demonstrated different accentuation in immunoreaction between individual cell domains in rat kidney (Bo-

Fig. 7. Photomicrographs of kidney sections incubated with anti-G $\alpha \mathrm{i}_{3}$ antibody. a, Cortical view showing apical staining of proximal tubules and faint glomerular staining. b, View of outer medulla showing weak staining of medullary collecting tubules. c, Staining in inner medulla is not remarkable. 

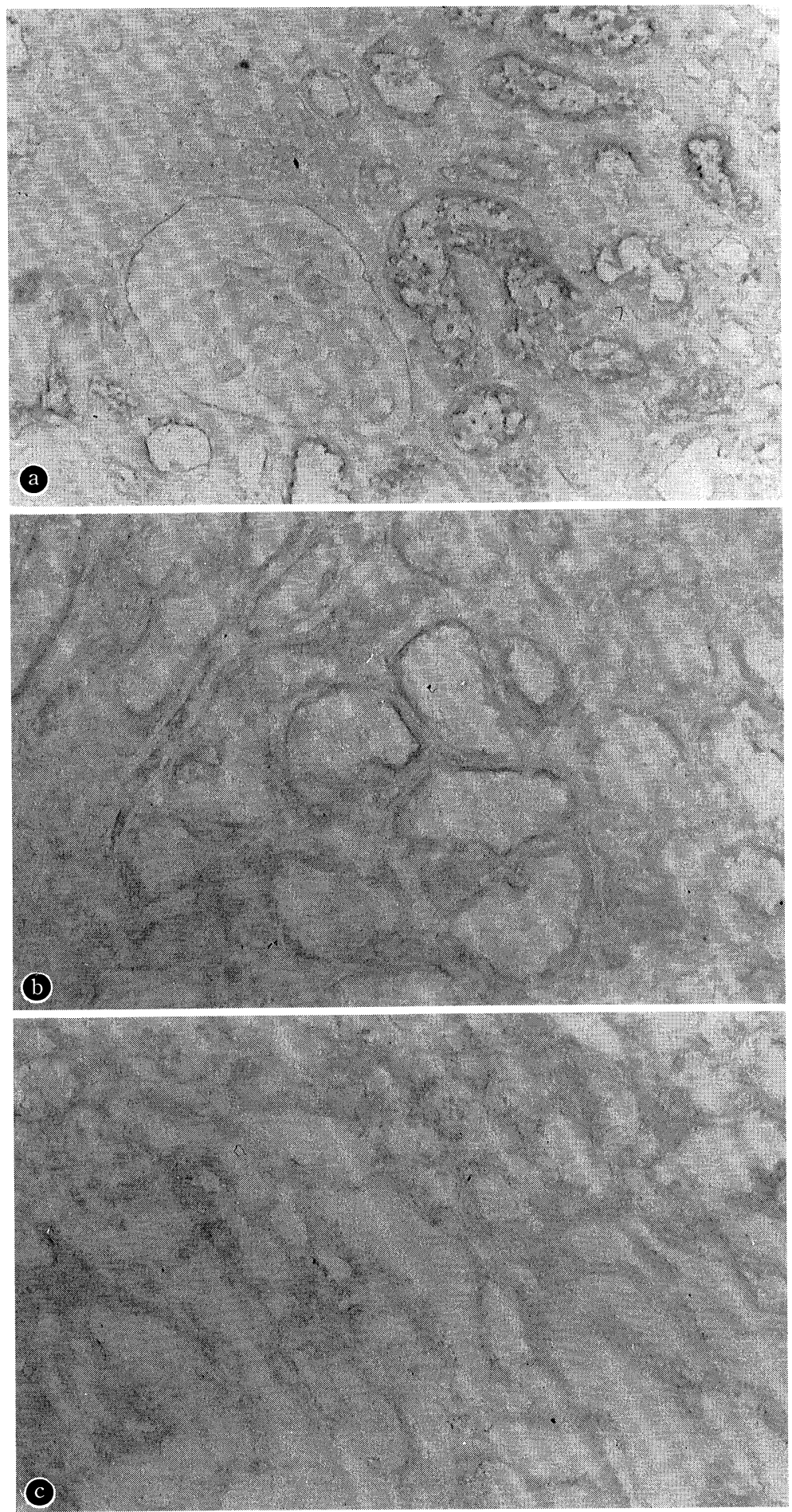

Fig. 7. 
koch et al. 1983; Hildebrandt et al. 1984). Further studies are necessary to elucidate precise localization of G-proteins in human nephron.

In the present study, findings obtained from immunoblots were largely consistent with those from immunohistochemistries. However, some discrepancies were noted. In immunoblotting studies, we recognized the presence of $\mathrm{G}_{\alpha} \mathrm{i}_{1,2}$ and $\mathrm{G}_{\alpha} \mathrm{i}_{3}$ in the glomerular membrane. On the contrary, there were no remarkable staining in glomeruli with any antibodies to these proteins. Renal medullae were more faintly stained than expected from the results obtained by immunoblots. Several possible reasons could be pointed out. One of them is a contamination caused during the sieving manipulations. Preparations on the 150 $\mu \mathrm{m}$-sized mesh may contain a small amount of cortical tubules. Another possibility is a sensitivity of the immunohistochemistry.

Recently, the localization of G-proteins in human glomeruli has been reported by Nitta et al. (1994). They demonstrated G $\alpha$ i proteins in glomeruli by histochemical technique using FITC-labeled antibodies. They also determined G $\alpha \mathrm{s}$ in the glomerular membrane fraction as a single form of 52-kDa protein. Altered method may contribute to the different results from our study.

In summary, we used immunoblotting and immunocytochemical methods to demonstrate the presence of G-proteins in human kidney. Our study is the first to demonstrate the expression of several G-protein $\alpha$ subunits in human nephron segments. Further studies may contribute to recognize the role of these proteins in the human kidney.

\section{References}

1) Birnbaumer, L., Abramowitz, J. \& Brown, A.M. (1990) Receptor-effector coupling by G-proteins. Biochim. Biophys. Acta, 1031, 163-224.

2) Bokoch, G.M., Katada, T., Northup, J.K., Hewlett, E.L. \& Gilman, A.G. (1983) Identification of the predominant substrate for ADP-ribosylation by islet activating protein. J. Biol. Chem., 258, 2071-2075.

3) Brunskill, N., Bastani, B., Hayes, C., Morrissey, J. \& Klahr, S. (1991) Localization and polar distribution of several G-protein subunits along nephron segments. Kidney Int., 40, 997-1006.

4) Cantiello, H.F., Patenaude, C.R. \& Ausiello, D.A. (1989) G-protein subunit, $\alpha$ i-3, activates a pertussis toxin sensitive $\mathrm{Na}$ channel from epithelial cell line A6. J. Biol. Chem., 264, 20867-20870.

5) Freissmuth, M., Casey, P.J. \& Gilman, A.G. (1989) G proteins control diverse pathways of transmembrane signaling. FASEB J., 3, 2125-2131.

6) Gilman, A.G. (1987) G proteins: Transducers of receptor-generated signals. Ann. Rev. Biochem., 56, 615-649.

7) Goldsmith, P.K., Gierschik, P., Milligan, G., Unson, C.G., Vinitsky, R., Malech, H.L. \& Spiegel, A.M. (1987) Antibodies directed against synthetic peptides distinguish between GTP-binding proteins in neutrophil and brain. J. Biol. Chem., 262, 1468314688.

8) Hildebrandt, J.D., Codina, J., Risinger, R. \& Birnbaumer, L. (1984) Identification of a $\gamma$ subunit associated with adenylyl cyclase regulatory proteins Ns and Ni. J. Biol. Chem., 259, 2039-2042. 
9) Jin, Z., Yanagisawa, H. \& Wada, O. (1992) Characterization of G-proteins in rat glomeruli. Jpn. J. Nephrol., 34, 349-352.

10) Laemmli, V.K. (1970) Cleavage of structural proteins during the assembly of the head of bacteriophage T4. Nature (Lond.), 227, 680-685.

11) Lowry, O.H., Rosebrough, J.J., Farr, A.L. \& Randall, R.J. (1959) Protein measurement with the Folin phenol reagent. J. Biol. Chem., 193, 265-275.

12) Mohrmann, M., Cantiello, H.F. \& Ausiello, D.A. (1987) Inhibition of epithelial $\mathrm{Na}+$ transport by atriopeptin, protein kinase $\mathrm{C}$, and pertussis toxin. Am. J. Physiol., 253, 372-376.

13) Murakami, T., Rossiter, K., Spiegel, A.M. \& Sacktor, B. (1989) Identification of multiple Gi subtypes and a novel $\mathrm{G}$ protein in bovine kidney cortex. Biochem. Pharmacol., 38, 4502-4505.

14) Nitta, K., Uchida, K., Kawashima, A., Tsutsui, T., Ozu, H., Naito, T., Yumura, W. \& Nihei, H. (1994) Identification of GTP-binding proteins in human glomeruli. Jpn. J. Nephrol., 36, 9-12.

15) Rodbell, M., Krans, H.M.J., Pohl, S.L., \& Birnbaumer, L. (1971) The glucagonsensitive adenyl cyclase system in plasma membranes of rat liver. IV. Effects of guanyl nucleotides on binding of ${ }^{125}$ I-glucagon. J. Biol. Chem., 246, 1872-1876.

16) Senkfor, S.I., Johnson, G.L. \& Berl, T. (1993) A molecular map of G protein $\alpha$ chains in microdissected rat nephron segments. J. Clin. Invest., 92, 786-790.

17) Simonds, W.F., Goldsmith, P.K., Codina, J., Unson, C.G. \& Spiegel, A.M. (1989a) $\mathrm{Gi}_{2}$ mediates $\alpha_{2}$-adrenergic inhibition of adenyl cyclase in platelet membranes: In situ identification with $\mathrm{G}_{\alpha}$ C-terminal antibodies. Proc. Natl. Acad. Sci. USA, 86, 78097813.

18) Simonds, W.F., Goldsmith, P.K., Woodaed, C.J., Unson, C.G. \& Spiegel, A.M. (1989b) Receptor and effector interactions of Gs. FEBS. Lett., 249, 189-194.

19) Spicher, K., Hinsce, K.D., Gausepohl, H., Frank, R., Rosenthal, W. \& Schultz, G. (1988) Immunochemical detection of the alpha-subunit of the G-protein, Gz in membranes and cytosols of mammalian cells. Biochem. Biophys. Res. Commun., 157, 883-890.

20) Spiegel, A.M., Weistein, L.S. \& Shenker, A. (1993) Abnormalities in G proteincoupled signal transduction pathways in human disease. J. Clin. Invest., 92, 11191125 .

21) Stow, J.L., Sabolic, I. \& Brown, D. (1991) Heterogenous localization of G-protein $\alpha$-subunits in rat kidney. Am. J. Physiol., 261, F831-F840.

22) Towbin, H., Staehelin, T. \& Gordon, J. (1979) Electrophoretic transfer of proteins from polyacrylamide gels to nitrocellulose sheets. Proc. Natl. Acad. Sci. USA, 79, $4350-4354$.

23) Zhou, J., Sims, C., Cang, C.H., Berti-Mattera, L., Hopfer, U. \& Douglas, J. (1990) Proximal tubular epithelial cells possess a novel 42-kilodalton guanine nucleotidebinding regulatory protein. Proc. Natl. Acad. Sci. USA, 87, 7532-7535. 